\title{
81. Muscarinic Agonists Release Adrenal Catecholamines by Mobilizing Intracellular $\mathrm{Ca}^{2+}$
}

\author{
By Yoshikazu Nakazato, Yutaka YamadA, Urara Tomita, \\ and Akira OHGA \\ Department of Pharmacology, Faculty of Veterinary Medicine, \\ Hokkaido University, Sapporo 060 \\ (Communicated by Setsuro EBASHI, M. J. A., Oct. 12, 1984)
}

Intracellulary stored $\mathrm{Ca}^{2+}$ is important in enzyme secretion from pancreatic acinar cells in response to cholinergic agents ${ }^{1,2)}$ which have been suggested to release $\mathrm{Ca}^{2+}$ from such a cellular store into the cytosol of acinar cells.3-(6) Caffeine could release catecholamine from perfused cat adrenal glands in the absence of extracellular $\mathrm{Ca}^{2+}$ suggesting that intracellular store of $\mathrm{Ca}^{2+}$ is also involved in the release of adrenal catecholamine. () Cat adrenal chromaffin cells are known to possess both muscarinic and nicotinic receptors of which the activation by respective agonist, pilocarpine and nicotine, causes release of both adrenaline and noradrenaline in a different ratio. ${ }^{8), 91}$ However, it remains uncertain whether intracellular store of $\mathrm{Ca}^{2+}$ participates in the receptor-mediated catecholamine secretion. We report here the possibility that acetylcholine mobilizes stored $\mathrm{Ca}^{2+}$ in chromaffin cells through the activation of muscarinic, but not nicotinic receptor and causes catecholamine secretion from perfused cat adrenal glands.

Perfused and isolated cat adrenal glands were prepared as described previously. ${ }^{101.11}$ The standard perfusion medium was a modified Locke solution of the following composition (mM) NaCl, 154 ; $\mathrm{KCl}, 5.6 ; \mathrm{CaCl}_{2}, 2.2 ; \mathrm{MgCl}_{2}, 1.2 ; \mathrm{Na}_{2} \mathrm{HPO}_{4}-\mathrm{NaH}_{2} \mathrm{PO}_{4}$ buffer (pH 7.0), 3 ; glucose 10. Pure O., was continuously bubbled through the solutions and the perfusion was carried out at room temperature (apprcximately $25^{\circ} \mathrm{C}$ ) in a flow rate of $0.6-0.7 \mathrm{ml} / \mathrm{min}$ by a peristaltic rump. All solutions contained physostigmine $\left(10^{-\tau} \mathrm{M}\right)$ to prevent hydrolysis of acetylcholine.

Application of acetylcholine $\left(10^{-5} \mathrm{M}\right)$, pilocarpine $\left(5 \times 10^{-4} \mathrm{M}\right)$, nicotine $\left(5 \times 10^{-6} \mathrm{M}\right)$ and excess $\mathrm{K}^{+}(\mathrm{KCl}, 56 \mathrm{mM})$ for $1 \mathrm{~min}$ to the adrenal gland during perfusion with standard Locke solution caused a significant increase in the release of adrenaline and noradrenaline. Dopamine was also released but its amount was only about $1 \%$ of the total catecholamine output. Acetylcholine, nicotine and excess $\mathrm{K}^{+}$in these concentrations released noradrenaline more than adrena- 
line and the reverse is the case for pilocarpine. Hexamethonium $\left(5 \times 10^{-4} \mathrm{M}\right)$ and atropine $\left(10^{-5} \mathrm{M}\right)$ completely blocked the responses to nicotine and pilocarpine, respectively, but both antagonists were always needed to prevent the response to acetylcholine. The response to excess $\mathrm{K}^{+}$was not affected by these antagonists. Most of these results agree with previous reports. ${ }^{8), 9}$ Furthermore, we found that a low concentration of acetylcholine (less than $10^{-6} \mathrm{M}$ ) caused a release of adrenaline and noradrenaline in the ratio approximately the same as that of their resting output which is a predominant release of adrenaline. However, with increasing the concentration of acetylcholine till $10^{-4} \mathrm{M}$, the percent of noradrenaline released progressively increased and the ratio of adrenaline to noradrenaline reversed. In the presence of hexamethonium $\left(5 \times 10^{-4} \mathrm{M}\right)$, the amounts of catecholamine released was markedly reduced. The effect of hexamethonium was much larger on the release of noradrenaline so that the ratio of adrenaline to noradrenaline in the residual muscarinic response became higher in all the concentration used.

In the absence of extracellular $\mathrm{Ca}^{2+}$, either nicotine or excess $\mathrm{K}^{+}$was ineffective in releasing catecholamine. On the other hand, acetylcholine and pilocarpine still increased catecholamine secretion the amounts of which widely varied from 5 to $25 \%$ of those obtained in the presence of $\mathrm{Ca}^{2+}$ in different adrenal glands. These responses were completely blocked by atropine, but not by hexamethonium. A representative liquid chromatogram was shown in Fig. 1 and the amounts of catecholamine released were summarized in Table I. In the absence of extracellular $\mathrm{Ca}^{2+}$, the ratio of adrenaline to noradrenaline released by acetylcholine was about $7: 3$ and this value was the same as that caused by pilocarpine.

According to the previous paper, ${ }^{7)}$ caffeine-induced catecholamine secretion in the absence of $\mathrm{Ca}^{2+}$ was potentiated by preloading the chromaffin cells with $\mathrm{Ca}^{2+}$. Thus, we studied the effect of $\mathrm{Ca}^{2+}$ loading on acetylcholine-induced response in the absence of extracellular

Table I. Release of adrenaline and noradrenaline from the isolated and perfused cat adrenal glands during perfusion with

$\mathrm{Ca}^{2+}$-free Locke solution containing EGTA $(0.1 \mathrm{mM})$

\begin{tabular}{lcccc}
\hline & $\begin{array}{l}\text { Resting } \\
\text { output }\end{array}$ & $\begin{array}{c}\text { Nicotine } \\
\left(5 \times 10^{-6} \mathrm{M}\right)\end{array}$ & $\begin{array}{c}\text { Acetylcholine } \\
\left(10^{-5} \mathrm{M}\right)\end{array}$ & $\begin{array}{c}\text { Pilocarpine } \\
\left(5 \times 10^{-4} \mathrm{M}\right)\end{array}$ \\
\hline Number of tests & 15 & 4 & 4 & 4 \\
Adrenaline & $0.47 \pm 0.08$ & $0.41 \pm 0.12$ & $1.97 \pm 0.38^{*}$ & $1.47 \pm 0.18^{*}$ \\
Noradrenaline & $0.31 \pm 0.06$ & $0.26 \pm 0.05$ & $0.95 \pm 0.06^{*}$ & $0.69 \pm 0.03^{*}$
\end{tabular}

Dopamine was undetectable during perfusion with $\mathrm{Ca}^{2+}$-free Locke solution. All values are mean nmoles \pm s.e. of catecholamines released per 5 min. $*=P<0.001$, when compared with each resting output. 


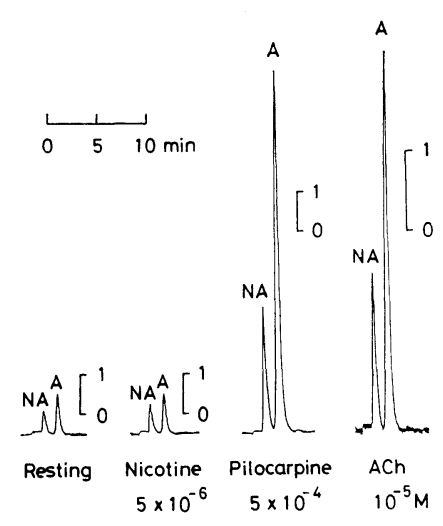

Fig. 1

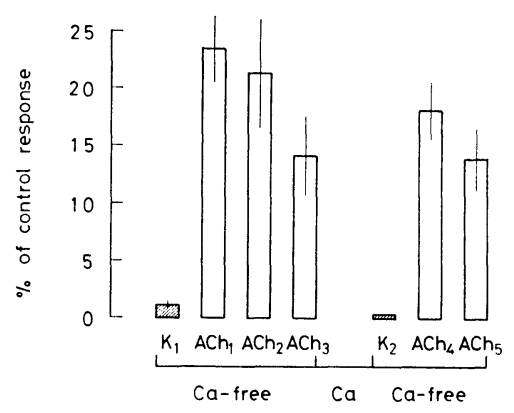

Fig. 2

Fig. 1. Chromatograms of catecholamines released from adrenal glands during perfusion with $\mathrm{Ca}^{2+}$-free Locke solution. Samples of adrenal effluent were collected into tubes kept on ice for successive 5 min periods. Catecholamines contained in the effluent were extracted according to the method described previously ${ }^{13)}$ and assayed by HPLC (Trirotar SR, Jasco, Tokyo, Japan) with an ODS-silica column (Catecholpak, Jasco). The native fluorescence was detected by means of a Spectrofluorometer (FP 540D, Jasco) fitted with filters providing excitation at $280 \mathrm{~nm}$ and emission at $315 \mathrm{~nm}$. Records show noradrenaline (NA) and adrenaline (A) released spontaneously (resting) and by nicotine $\left(5 \times 10^{-6} \mathrm{M}\right)$, pilocarpine $\left(5 \times 10^{-4} \mathrm{M}\right)$ and acetylcholine $(\mathrm{ACh})\left(10^{-5} \mathrm{M}\right)$ which were respectively applied 15,30 and $45 \mathrm{~min}$ after the start of exposure to $\mathrm{Ca}^{2+}$-free Locke solution containing EGTA $(0.1 \mathrm{mM})$ for $1 \mathrm{~min}$ in a single preparation. Vertical bars indicate arbitrary unit of fluorescent intensity. Left upper horizontal bar is time scale.

Fig. 2. Restoration of catecholamine release in response to acetylcholine in $\mathrm{Ca}^{2+}$-free Locke solution by reintroduction of $\mathrm{Ca}^{2+}$. Twenty-five min after the start of exposure to $\mathrm{Ca}^{2+}$-free Locke solution containing EGTA $(0.1 \mathrm{mM})$, the glands were stimulated sequentially with excess $\mathrm{K}^{+}(\mathrm{KCl}, 56 \mathrm{mM})\left(\mathrm{K}_{1}\right)$ and acetylcholine $\left(10^{-5} \mathrm{M}\right)\left(\mathrm{ACh}_{1}, \mathrm{ACh}_{2}, \mathrm{ACh}_{3}\right)$ at 15 min intervals. After $\mathrm{ACh}_{3}$, the perfusion solution was changed to standard Locke (Ca) and left for 25 min without any stimulation until it was switched back to $\mathrm{Ca}^{2+}$-free solution (Ca-free) again. During the second exposure to $\mathrm{Ca}^{2+}$-free solution, three responses $\left(\mathrm{K}_{2}, \mathrm{ACh}_{4}, \mathrm{ACh}_{5}\right)$ were sequentially obtained at $15 \mathrm{~min}$ intervals. The amounts of catecholamine released by the secretagogues were expressed as a percent of each response obtained preceding the exposure to $\mathrm{Ca}^{2+}$-free solution (data not shown). The assay of catecholamine (adrenaline) was performed by a conventional fluorimetric method. ${ }^{14)}$ All values are mean \pm s.e. of 4 experiments.

$\mathrm{Ca}^{2+}$. Fig. 2 shows that the secretory response to acetylcholine gradually declined on repetition. However, when the perfusion solution was switched to the standard Locke solution for $25 \mathrm{~min}$ and then back to $\mathrm{Ca}^{2+}$-free solution, the response to acetylcholine was partially recovered even though excess $\mathrm{K}^{+}$remained ineffective.

These results suggest that the adrenal chromaffin cells possess 
intracellularly stored $\mathrm{Ca}^{2+}$ which is mobilized by acetylcholine through the activation of muscarinic receptors and causes catecholamine secretion. On the other hand, nicotine like excess $\mathrm{K}^{+}$may increase catecholamine secretion only by increasing the entry of extracellular $\mathrm{Ca}^{2+}$. In perfused rat adrenal glands, it has been reported that a considerable amount of catecholamine was still released by acetylcholine in the absence of extracellular $\mathrm{Ca}^{2+}{ }^{12)}$ We also found that acetylcholine, but not nicotine or excess $\mathrm{K}^{+}$, caused increase in catecholamine secretion from rat and guinea pig adrenal glands during perfusion with $\mathrm{Ca}^{2+}$-free Locke solution containing EGTA (0.1-1 mM). Furthermore, acetylcholine also released catecholamine from guinea pig adrenal gland during exposure to $\mathrm{Ca}^{2+}$-free, $\mathrm{K}^{+}$-rich solution in which $\mathrm{NaCl}$ of standard Locke solution was replaced by $\mathrm{KCl}$ (data not shown). In such a $\mathrm{K}^{+}$-rich solution, chromaffin cell membrane must be completely depolarized and thus acetylcholine cannot exert its effect through the membrane excitability. It may be possible that an active site for acetylcholine is located inside the chromaffin cell. In any case, our results suggest that muscarinic receptor-linked intracellular $\mathrm{Ca}^{2+}$ store is present in the adrenal chromaffin cells of wide variety of species and may play an important role in the secretion of catecholamine under the physiological condition.

We thank Dr. S. Ito for his advice and reading the manuscript. This work was supported in part by Grant from the Ministry of Education of Japan $(56560295,57480076)$ and by the Research Grant for 1980 from the Naito Foundation.

\section{References}

1) Williams, J. A., and Chandler, D. E.: Am. J. Physiol., 228, 1729-1732 (1975).

2) Petersen, O. H., and Ueda, N.: J. Physiol., 254, 583-606 (1976).

3) Shelby, H. T. et al.: J. Clin. Invest., 58, 1482-1493 (1976).

4) Chardler, D. E., and Williams, J. A.: J. Cell Biol., 76, 371-385 (1978).

5) — : ibid., 76, 386-399 (1978).

6) Stolze, H., and Schulz, I.: Am. J. Physiol., 238, G338-G348 (1980).

7) Poisner, A. M.: Proc. Sec. exp. Biol. Med., 142, 103-105 (1973).

8) Douglas, W. W., and Poisner, A. M.: Nature, 208, 1102-1103 (1965).

9) Rubin, R. P., and Miele, E.: J. Pharmac. exp. Ther., 164, 115-121 (1968).

10) Douglas, W. W., and Rubin, R. P.: J. Physiol., 159, 40-57 (1961).

11) Ito, S., Nakazato, Y., and Ohga, A.: Br. J. Pharmac., 65, 319-330 (1979).

12) Wakade, A. R.: J. Physiol., 313, 463-480 (1981).

13) Salzman, S. K., and Sellers, M. S.: J. Chromatography, 232, 29-37 (1982).

14) Anton, A. H., and Sayre, D. F.: J. Pharmac. exp. Ther., 138, 360-375 (1962). 